\title{
Tolerance of upland rice genotypes to water deficit
}

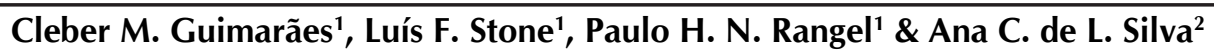

\begin{abstract}
Water deficit is one of the environmental factors that cause a great reduction in the upland rice grain yield. The objective of this study was to evaluate genotypes of upland rice with broad genetic diversity for tolerance to this stress and to identify secondary traits for evaluation of this tolerance. Sixty-four genotypes were evaluated during two years at the Experiment Station of EMATER, in Porangatu, GO, under wellwatered and water deficit conditions. The genotypes showed differences in grain yield and were influenced differently by the water treatments, both under a mild water deficit in the first year and under a severe one in the second year. The genotype grain yield under water deficiency was significantly and positively correlated with tiller fertility, number of panicles $\mathrm{m}^{-2}, 100$-grain weight, and plant height, and negatively with spikelet sterility and the number of days for the occurrence of $50 \%$ panicle emergence. It was also observed that the most productive genotypes under water deficit conditions showed lower leaf temperature, indicating improved water status. Nine genotypes were productive in both water conditions and three were productive only when well-watered.
\end{abstract}

Key words: Oryza sativa, irrigation, grain yield, leaf temperature

\section{Tolerância à deficiência hídrica de genótipos de arroz de terras altas}

\section{RESUMO}

A deficiência hídrica é um dos fatores que mais limitam a produtividade do arroz de terras altas. O objetivo deste trabalho foi avaliar genótipos de arroz de terras altas com ampla divergência genética quanto à tolerância a esse estresse e identificar caracteres secundários de avaliação para essa tolerância. Para tanto foram avaliados, durante dois anos, 64 genótipos na Estação Experimental da EMATER, em Porangatu, GO, em duas condições hídricas, com e sem deficiência hídrica. Os genótipos diferiram quanto à produtividade e foram influenciados diferentemente pela deficiência hídrica, tanto pela moderada $\left(1^{\circ}\right.$ ano $)$ como pela severa $\left(2^{\circ}\right.$ ano). O comportamento produtivo dos genótipos sob deficiência hídrica correlacionou-se, positiva e significativamente, com a fertilidade de perfilhos, número de panículas $\mathrm{m}^{-2}$, massa de 100 grãos e altura da planta e negativamente com a esterilidade de espiguetas e o número de dias para a ocorrência de $50 \%$ da emissão das panículas. Verificou-se também que os genótipos mais produtivos em condições de deficiência hídrica apresentaram menor temperatura das folhas sinalizando melhor estado hídrico. Identificaram-se nove genótipos produtivos em ambas as condições hídricas e três produtivos somente sob irrigação adequada.

Palavras-chave: Oryza sativa, irrigação, produtividade, temperatura das folhas

\footnotetext{
${ }^{1}$ Embrapa Arroz e Feijão, C.P. 179, CEP 75375-000, Santo Antônio de Goiás, GO. Fone: (62) 3533-2178. E-mail: cleber.guimaraes@embrapa.br; luis.stone@embrapa.br; paulo.rangel@embrapa.br

${ }^{2}$ Doutoranda do Curso de Pós-Graduação em Agricultura da FCA/UNESP, C.P. 237, CEP 18610-307, Botucatu, SP. Fone: (14) 3882-2818. E-mail: analima.agro@gmail.com
} 


\section{INTRODUCTION}

In the mid-1960s, scientists developed high-yielding crop varieties of rice and wheat that were subsequently released to farmers in Latin America and Asia. The success of these varieties was characterized as a "Green Revolution". Early rice and wheat varieties were rapidly adopted in tropical and subtropical regions with good irrigation systems or reliable rainfall. These varieties devoted much of their energy to producing grain and relatively little to producing straw or leaf material. They also responded better to fertilizer than traditional varieties and yielded substantially more grain than previous varieties (Evenson \& Gollin, 2003), helping in preventing hunger. As mentioned, the largest initial impacts on rice production were in irrigated areas and in rainfed lowland with good water control. But outside of these environments, varietal improvement was slower. This is worsened when one considers that increasing the productivity of irrigated areas alone will not suffice to meet the growing demand for rice and that the expansion of planted area in some countries confronted with the unavailability of water, and others, with strict environmental laws that protect the wetland ecosystem, considered as conservation areas. Therefore, it is increasingly evident dependence of the production of aerobic rice ecosystems, which often have climatic limitations.

Brazilian savannas or "Cerrado", which cover an area of 200 million ha, have high potential for agricultural production. Exploitation of the "Cerrado" increased in the 1960s and 1970s, and upland rice played a crucial role in bringing these areas under cultivation. The low fertility, acidic soils of the region limited the cultivation of crops other than rice. Local varieties of the tropical japonica group tolerated these soil limitations, allowing the exploitation of large areas. Since the early 1980s, the upland rice production in "Cerrado" is moving from southwest towards northwest, i.e., from a more drought risky towards a less drought risky savanna area. A significant proportion of low-risk rice land is in the State of Mato Grosso, especially in its central-north region (Pinheiro et al., 2006), and in the south of the State of Pará.

The expansion of planting in these areas will certainly grow out of sync with the demands of increased production, given the rigid environmental institutions established by the use of these lands and increasing production costs for the transportation of agricultural inputs and grain produced in more distant regions of the major centers of consumption.

There is a concept that is becoming increasingly clear: the upland rice must adapt to abiotic stress similar to other crops such as soybeans and corn, otherwise it will not be feasible in rotation systems. However, one must consider that the ancestors of this crop were semi-aquatic and that it is not yet fully adapted to the aerobic systems, because of its limited tolerance to water deficit. To reduce the risk for the crop, beyond the most appropriate agronomic practices that enable plants to better use soil water, it is recommended new cultivars with greater capacity to adapt to the irregular distribution of rainfall (Manickavelu et al., 2006).

Drought resistance is a complex phenomenon comprising a number of physio-biochemical processes at both cellular and organismic levels at different stages of plant development. It includes drought escape via a short life cycle or developmental plasticity, drought avoidance via enhanced water uptake and reduced water loss, drought tolerance via osmotic adjustment, antioxidant capacity, and desiccation tolerance (Yue et al., 2006). These authors verified that the yield loss and harvest index reduction under drought stress were associated with the reduction of spikelet fertility, fertile panicle rate, biomass and grain weight.

A deep root system could improve the adaptation of rice during drought through greater capacity for water extraction, thus maintaining high plant leaf water status. Kamoshita et al. (2004) showed that the relationship between root length density and soil water extraction rate by the end of a shorter drought period was positive in the $40-50 \mathrm{~cm}$ layer, showing the advantage of deep root development for extracting water from deep soils when drought period is not extended. These authors related that there is a large genotypic variability for root traits and a clearer definition of drought development (e.g., rate of soil drying) may be needed to understand genotype by environment interaction for deep root development.

Numerous rice secondary characteristics have been suggested to help plant breeders in their selections to drought resistance. Most of these traits are not used in the selection, as they are not practical for selection purposes, exhibit low heritability, or are not highly correlated with grain yield. The use of managed drought stress, where it can be imposed at specific periods, has been shown to increase the heritability of yield under stress to values similar to those obtained for yield in well-watered conditions. It has now been demonstrated that drought-tolerant upland rice can be bred by directly selecting for yield in stress environments (Bernier et al., 2008).

The objective of this study was to evaluate the drought tolerance of genotypes of upland rice with broad genetic diversity and to identify secondary traits for evaluating this tolerance.

\section{Material And Methods}

The experiments were conducted on an Oxisol at the Experimental Station of EMATER, in Porangatu-GO, located at $13^{\circ} 18^{\prime} 31^{\prime \prime}$ South latitude and $49^{\circ} 06^{\prime} 47^{\prime \prime}$ West longitude, at an altitude of $391 \mathrm{~m}$. The climate is tropical savanna, megathermal, Aw according to the Köppen classification. Climatic data during periods of conducting the experiments in 2006 and 2007 are shown in Figure 1.

The experiments were sown on 11/06/2006 and 12/05/2007 in plots with three rows $4 \mathrm{~m}$ long and $0.35 \mathrm{~m}$ apart, with 18 seeds $\mathrm{m}^{-1}$. The demand of plants for nitrogen, phosphorus and potassium was supplied with the application of 16 , 120 and $64 \mathrm{~kg} \mathrm{ha}^{-1}$ of $\mathrm{N}, \mathrm{P}_{2} \mathrm{O}_{5}$ and $\mathrm{K}_{2} \mathrm{O}$, respectively. The nitrogen topdressing was done with $30 \mathrm{~kg} \mathrm{~N} \mathrm{ha}^{-1}, 55$ days after emergence. The weed control was carried out with oxadiazon at a dose of $1000 \mathrm{~g}$ a.i. ha ${ }^{-1}$ in pre-emergence. Sixty-four genotypes of upland rice (Oryza sativa L.) were evaluated in randomized block design with three replications. Two experiments were conducted in each year, the first was well-watered throughout plant development and the other only up to 25 days after emergence, when water deficiency was applied. 

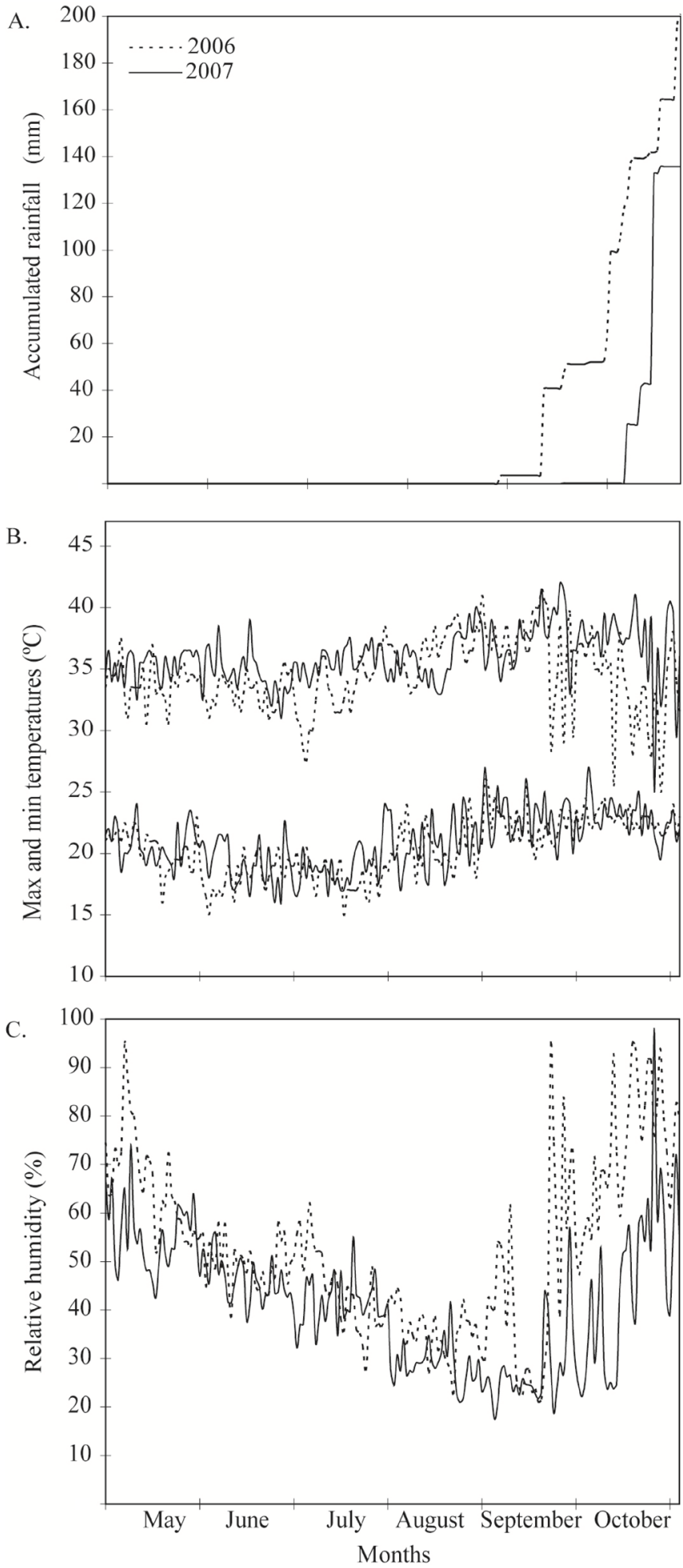

Figure 1. Accumulated rainfall (A), maximum and minimum temperatures (B) and mean relative humidity (C) during the experiments in 2006 and 2007 at the Experimental Station of EMATER, Porangatu, GO

Irrigations were conducted in the first experiment and during the period without water deficit of the second experiment when the soil matric potential at $0.15 \mathrm{~m}$ depth, measured with tensiometer, recorded $-0.025 \mathrm{MPa}$ (Stone et al., 1986), using a self-propelled irrigation bar. The procedure for determining the amount of water to be applied was based on the water retention curve, calculating the difference between the moisture content at $-0.008 \mathrm{MPa}$ (field capacity) and $-0.025 \mathrm{MPa}$. This difference, multiplied by the depth of $40 \mathrm{~cm}$, indicated the net irrigation depth, which divided by the equipment efficiency, resulted in a gross irrigation depth of $25 \mathrm{~mm}$.

During the period of water deficit, when the tensiometer indicated the time of irrigation in well-watered treatment, 12.5 $\mathrm{mm}$ in water deficit treatment was applied. The rainfall was considered in irrigation management. In the first year it rained $200 \mathrm{~mm}$ during the rice cycle, being $60 \mathrm{~mm}$ in the most critical stage to water deficit. In the second year the total rainfall was $135 \mathrm{~mm}$, all in the end of rice cycle, a stage less critical to water deficit (Figure 1).

Joint analysis was performed considering the two experiments, with and without water deficit, and the two years of trials and also individual analysis per year was performed. Grain yield, spikelet sterility, tiller fertility, number of grains panicle ${ }^{-1}$, number of panicle $\mathrm{m}^{-2}, 100$-grain weight, plant height and number of days for the occurrence of $50 \%$ of flowering were evaluated by conventional methods, and the temperature of the leaves according to Guimarães et al. (2010).

\section{RESULTS AND Discussion}

Preliminary analysis of variance showed that genotypes were differently influenced by the years, since the genotype $x$ year interaction was significant for all variables. This can be explained by different climatic conditions, especially rainfall distribution, that occurred during the periods of conducting the experiments in 2006 and 2007 (Figure 1), as mentioned before. Therefore, the analysis was conducted separately by year (Table 1).

The genotypes showed differences in grain yield, both in 2006 and in 2007, and were influenced differently by the water treatments, since the water levels $\mathrm{x}$ genotypes interaction was significant in both years of evaluation. Lafitte et al. (2006) also observed variability in the grain yield of rice genotypes when subjected to water deficit. In the first year of the experiment, mean grain yield of $1470 \mathrm{~kg} \mathrm{ha}^{-1}$ and $2209 \mathrm{~kg} \mathrm{ha}^{-1}$ were found respectively in water stress and well-watered conditions. In 2007 , the grain yield in these two water conditions were 280 $\mathrm{kg} \mathrm{ha}^{-1}$ and $2029 \mathrm{~kg} \mathrm{ha}^{-1}$, respectively. The mean effect of water deficit on grain yield of the genotypes was 33.4 and $86 \%$ in 2006 and 2007, respectively. Based on these effects, the water deficiency can be classified as moderate and severe, respectively, according to Jongdee et al. (2006).

In the two years the genotypes differed in all agronomic components with the exception of the tiller fertility in 2006 . It was also noted that in 2006 the interaction water levels $\mathrm{x}$ genotypes was significant for spikelet sterility, number of panicles $\mathrm{m}^{-2}, 100$-grain weight and plant height. Therefore, these variables were responsible for the different performance of genotype grain yield under mild water deficit and wellwatered conditions. On the other hand, in 2007, under severe water stress, the interaction water levels $\mathrm{x}$ genotypes was significant for all agronomic components, signaling that they all contributed to the different performance of genotype grain yield under both water conditions. 
Table 1. Summary of analysis of variance for grain yield (GY), spikelet sterility (SS), tiller fertility (TF), number of grains panicle $^{-1}$ (GP), number of panicles $\mathrm{m}^{-2}$ (PAN), 100-grain weight (100GW), plant height (PH) and flowering (FLO)

\begin{tabular}{|c|c|c|c|c|c|c|c|c|c|}
\hline \multirow{2}{*}{$\begin{array}{l}\text { Source of } \\
\text { variation }\end{array}$} & \multirow{2}{*}{ D.F. } & \multicolumn{8}{|c|}{ Error mean square } \\
\hline & & GY & SS & TF & GP & PAN & 100GW & PH & FLO \\
\hline \multicolumn{10}{|c|}{ Year 2006} \\
\hline Water levels $(A)$ & 1 & $52412098 \star \star$ & $56612.0^{\star \star}$ & $220.3^{\text {ns }}$ & $6725.1^{\star \star}$ & $133877.3^{\star \star}$ & $9.00 * \star$ & $8730.6^{\star \star}$ & $1418.3^{\star \star}$ \\
\hline Error & 4 & 790390 & 504.2 & 240.6 & 313.4 & 3744.6 & 0.39 & 199.6 & 50.9 \\
\hline Genotypes (G) & 63 & $1843276^{* *}$ & $670.5^{* *}$ & $114.1^{\text {ns }}$ & $978.5^{* *}$ & $9468.2 * *$ & $0.85^{* *}$ & $1042.3^{* *}$ & $1197.2^{\star *}$ \\
\hline$A \times G$ & 63 & $560615^{\star *}$ & $282.7^{* *}$ & $97.1^{\text {ns }}$ & $304.9^{\text {ns }}$ & $3585.1^{\text {** }}$ & $0.08^{* *}$ & $118.0^{*}$ & $8.4^{\mathrm{ns}}$ \\
\hline Error & 252 & 231887 & 151.7 & 92.9 & 231.8 & 2447.7 & 0.05 & 83.4 & 7.4 \\
\hline CV $(\%)$ & & 26.17 & 35.55 & 11.71 & 18.71 & 21.52 & 7.82 & 7.94 & 2.65 \\
\hline \multicolumn{10}{|c|}{ Year 2007} \\
\hline Water levels $(A)$ & 1 & $293877512^{\star \star}$ & $1469.4^{\mathrm{ns}}$ & 154128.0 ** & $284000.6^{\star \star}$ & $647391.4^{\star *}$ & $199.32 * \star$ & $292162.7^{\star *}$ & $211782.1^{\text {** }}$ \\
\hline Error & 4 & 882088 & 669.7 & 89.1 & 815.4 & 1633.8 & 0.03 & 220.4 & 68.8 \\
\hline Genotypes (G) & 63 & $2552595^{* *}$ & $1768.2^{\star *}$ & $2720.5^{* *}$ & $4533.6^{* *}$ & $28744.0 * *$ & $2.92^{* *}$ & $2165.0 * *$ & $3588.0 * *$ \\
\hline$A \times G$ & 63 & $1102427^{* *}$ & $2686.3^{* *}$ & $1778.2^{* *}$ & $2361.9 * *$ & $9717.0^{* *}$ & $1.70^{* *}$ & $2115.6^{* *}$ & $6362.3^{* *}$ \\
\hline Error & 252 & 209559 & 131.4 & 96.6 & 308.5 & 1640.0 & 0.09 & 66.2 & 60.3 \\
\hline CV $(\%)$ & & 39.66 & 32.58 & 16.10 & 24.63 & 28.69 & 15.59 & 11.93 & 9.59 \\
\hline
\end{tabular}

ns - $F$ not significant at 0,05 level, * $-F$ significant at 0,05 and ${ }^{* \star}$ - $F$ significant at 0,01

To meet the conditions of water stress-producing regions of upland rice as the Cerrado, where during the growing season the rainfall distribution may have some irregularities, the drought tolerance should be an aggregated characteristic of the genotype, since most of the time the rainfall distribution is adequate. Therefore, it was considered in the selection the grain yield under both conditions: with and without water stress. Jongdee et al. (2006) reported that genotypes can be developed showing good grain yield in water stress conditions and, at the same time, being responsive to favorable soil moisture, provided they are evaluated in both environments. According to the authors, it is feasible for moderate water stress, when the reduction in productivity is less than $50 \%$. However, under severe stress, mechanisms for escape or tolerance to water deficit are required. These results differ from the information presented, because even under moderate water stress, when there was a $33.4 \%$ reduction in grain yield, as described above, different performance of the genotypes was observed when subjected to water deficit or well-watered conditions.

According to the distribution of genotypes in four quartiles, considering mean grain yield under well-watered and water deficit conditions, 10 - CA780308 (Amarelão Ligeiro), 12 CA780329 (Comum Creolo), 13 - CA780336 (Pratão Goiano), 45 - CA870092 (Branquinho), 47 - CA870139 (Noventinha), 50 - CA870177 (Arroz Roxo ou Caqui), 59 - CNA0000937 (Catalão), 60 - CNA0001420 (Carreon), and 63 - CNA0004623 (Pico Negro) were selected for producing 10\% above mean grain yield, $2430 \mathrm{~kg} \mathrm{ha}^{-1}$ and $2232 \mathrm{~kg} \mathrm{ha}^{-1}$ in the well-watered treatment and $1617 \mathrm{~kg} \mathrm{ha}^{-1}$ and $308 \mathrm{~kg} \mathrm{ha}^{-1}$ under water deficit, respectively in the first and second years (Figure 2), standing in the first quartile.

Genotypes 1 - CA780044 (Cateto Seda), 18 - CA79030118 (Ligeiro), and 57 - CA980023-57 (Arroz Canela de Ferro) were productive under well-watered conditions, but were more sensitive to water deficit.

Rice cultivars combining improved drought tolerance with yield potential under favorable conditions are, hence, the most promising and deliverable technology for increasing productivity in conditions of mild water deficit in the soil (Jongdee et al., 2006; Serraj et al., 2009).
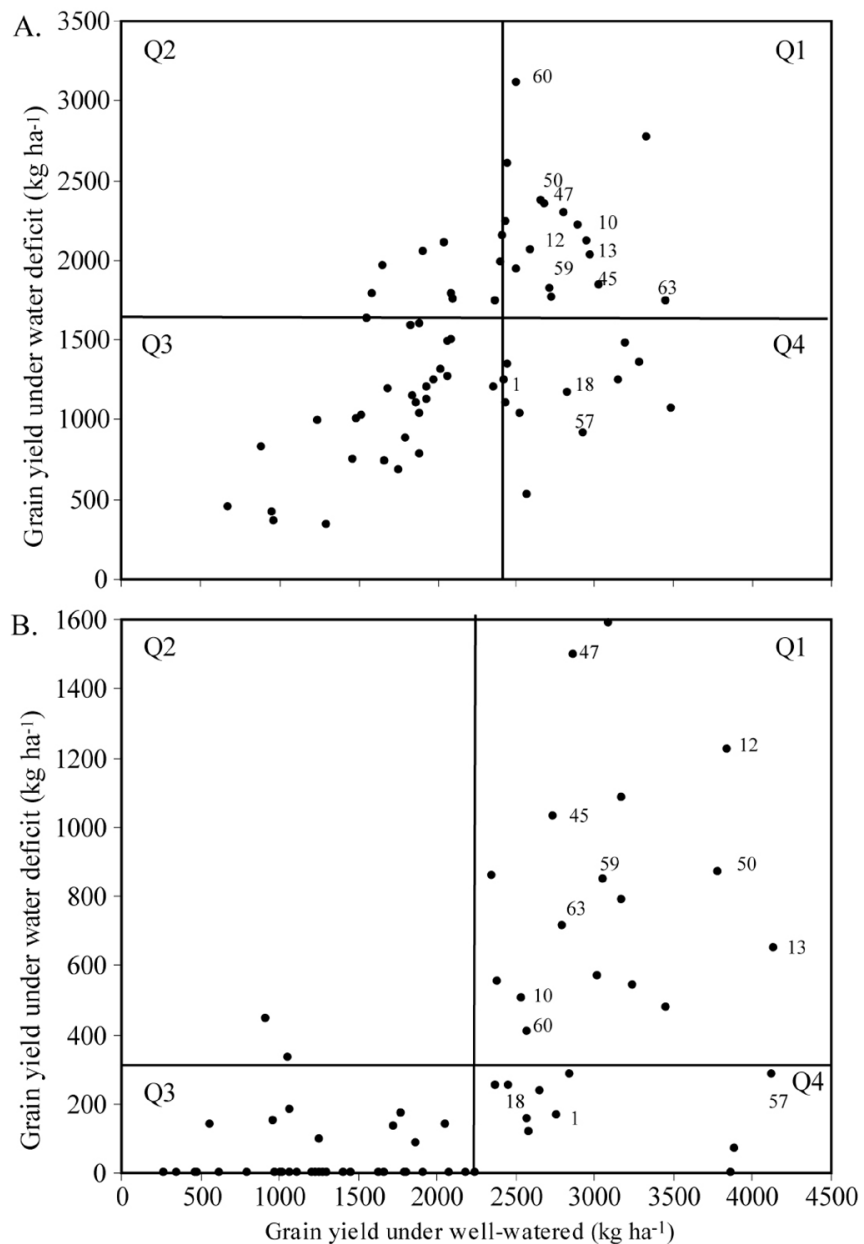

1 - CA780044 (Cateto Seda), 10 - CA780308 (Amarelão Ligeiro), 12 - CA780329 (Comum Creolo), 13 - CA780336 (Pratão Goiano), 18 - CA790301-18 (Ligeiro), 45 - CA870092 (Branquinho), 47 - CA870139 (Noventinha), 50 - CA870177 (Arroz Roxo ou Caqui), 57 - CA98002357 (Arroz Canela de Ferro), 59 - CNA0000937 (Catalão), 60 - CNA0001420 (Carreon), and 63 - CNA0004623 (Pico Negro)

Figure 2. Distribution of upland rice genotypes in four quartiles $(\mathrm{Q})$ according to the mean grain yield under well-watered and water deficit conditions in the year 2006 (A) and 2007 (B)

The genotype grain yield under water deficiency was significantly and positively correlated with tiller fertility, 
number of panicles $\mathrm{m}^{-2}$, 100-grain weight, and plant height, and was negatively correlated with spikelet sterility, number of days for the occurrence of $50 \%$ panicle emergence and leaf temperature (Table 2). The number of grains panicle ${ }^{-1}$ had no influence on grain yield, as also observed by Lafitte et al. (2004). It was observed that the most productive genotypes in water stress conditions were those higher, with the highest number of panicles per unit area, not very dense, low spikelet sterility and well-formed grain.

Table 2. Coefficient of simple correlation between mean grain yield (GY), spikelet sterility (SS), number of grains panicle ${ }^{-1}(\mathrm{GP})$, tiller fertility (TF), number of panicles per $\mathrm{m}^{2}$ (PAN), 100-grain weight (100GW), flowering (FLO), plant height $(\mathrm{PH})$ and leaf temperature (LT), under water deficit

\begin{tabular}{lcccccccc}
\hline & SS & GP & TF & PAN & 100GW & FLO & PH & LT \\
GY & -0.784 & -0.13 & 0.47 & 0.496 & 0.646 & -0.22 & 0.47 & -0.386 \\
& $<0.01$ & 0.199 & $<0.01$ & $<0.01$ & $<0.01$ & 0.028 & $<0.01$ & $<0.01$ \\
SS & & 0.237 & -0.37 & -0.341 & -0.668 & 0.274 & -0.326 & 0.271 \\
& & 0.017 & $<0.01$ & $<0.01$ & $<0.01$ & $<0.01$ & $<0.01$ & 0.03 \\
GP & & & -0.221 & -0.343 & -0.215 & 0.236 & 0.088 & 0.008 \\
& & & $<0.01$ & $<0.01$ & 0.032 & 0.018 & 0.383 & 0.947 \\
TF & & & 0.733 & 0.357 & -0.517 & 0.22 & -0.162 \\
& & & & $<0.01$ & $<0.01$ & $<0.01$ & 0.028 & 0.201 \\
PAN & & & & 0.181 & -0.379 & 0.152 & -0.150 \\
& & & & & 0.072 & $<0.01$ & 0.132 & 0.238 \\
100GW & & & & & -0.451 & 0.2 & -0.143 \\
& & & & & & $<0.01$ & 0.046 & 0.206 \\
FLO & & & & & & 0.405 & -0.099 \\
& & & & & & & $<0.01$ & 0.437 \\
PH & & & & & & -0.102 \\
& & & & & & & 0.422 \\
\hline
\end{tabular}

${ }^{1}$ In each cell, the first value corresponds to the correlation coefficient and the second to the significance

Yue et al. (2006) also observed that yield loss under drought stress were associated with the increase of spikelet sterility and reduction of fertile panicle rate and grain weight, but was not significantly correlated with flowering time. Lafitte \& Courtois (2002), however, showed the advantages of earlier flowering over later flowering in terms of higher spikelet fertility, higher harvest index, and higher yield.

According to Serraj et al. (2009), the strong effects of drought on rice grain yield are largely due to reduction in spikelet fertility and panicle exertion. Reproductive development from meiosis in the spore mother cells to fertilization and the early seed establishment was extremely sensitive to drought. This stress causes various structural and functional disruptions in reproductive organs, leading to failure of fertilization or premature abortion of the seed. Drought stress also inhibits peduncle elongation, and rewatering can only partially restore elongation. The spikelets left inside the leaf sheath are usually sterile, resulting in poor yield, which indicates that peduncle elongation may play a major role in panicle exertion and fertility under stress (Serraj et al., 2009).

Rice genotypes that produce a higher grain yield under drought are those able to maintain better plant water status, especially when stress occurs around flowering and grain formation (Fukai et al., 2008), since leaf and panicle water potential are very highly associated with panicle exertion and anther dehiscence.
Usually rice genotypes with greater plant height are often larger in overall plant size, intercept more light and use water faster by transpiration, leading to lower plant water status (Kamoshita et al., 2004), higher dead leaf scores, and more spikelet sterility (Kato et al., 2007). However, according to the report of Fukai \& Cooper (1995), the genotypes more adapted to upland ecosystem had fewer tillers, but higher. They had few roots, but more robust and deeper, with better distribution of secondary and tertiary roots throughout the soil profile. These roots showed greater outside diameter and also of its xylem vessels, as well as lower resistance to water flow. These characteristics were reflected in plant water status, measured by relative water content and water potential in leaves, or even, as measured by the level of curling of leaves. On the other hand, plants with more tillers tended to have more roots, but shorter, particularly in secondary and tertiary tillers, which develop later. A deep root system with higher root density is likely to be useful under intermittent drought if growing conditions permit root development at depth (Kamoshita et al., 2004).

It was also observed that denser panicles, with more grains, had a higher spikelet sterility (Table 2). Similar results were not observed in well irrigated conditions, since the correlation coefficient between these variables was $0.022(\mathrm{p}=0.802)$, while under water stress the correlation was $0.237(\mathrm{p}=0.02)$. Additionally, it was found that plants with dense panicles were those who had lower fertility of tillers, $r=-0.221(p<0.01)$, also lower number of panicles $\mathrm{m}^{-2}, \mathrm{r}=-0.343(\mathrm{p}<0.01)$ and lighter grains, $r=-0.215(\mathrm{p}=0.03)$.

The data suggest that for soil and climatic conditions of the Experimental Station, the capacity of genotypes for photosynthesizing does not meet adequately the demand of storage sites for carbohydrates.

The correlation coefficient between the genotype grain yield and leaf temperature was $-0.386(p<0.01)$, so the most productive genotypes under water deficit showed a lower temperature of the leaves, indicating better water status of these genotypes. Canopy temperature is a sensitive indicator of plant stress level, and has long been associated with stomatal conductance at the leaf level. During a period of water shortage, plants conserve water by closing their stomata, raising their internal temperature. Leaf temperature is thus correlated with the plant stress level (Serraj et al., 2009). Hirayama et al. (2006) reported that rice genotypes with lower leaf temperature during water deficit showed higher rates of transpiration, photosynthesis and grain yield.

The correlation coefficient between spikelet sterility and leaf temperature was $0.271(\mathrm{p}=0.03)$. The data confirm the observations of Jongdee et al. (2002) and Guimarães et al. (2010), since these authors found that the genotypes that maintained high leaf water potential showed lower spikelet sterility. Additionally, Pinheiro (2003) and Yue et al. (2006) found that spikelet sterility is the component of productivity more sensitive to water stress.

\section{Conclusions}

1. The rice genotypes evaluated differ in grain yield potential and respond differently to water deficit. 
2. The grain yield under water deficit is negatively correlated with leaf temperature.

3. The genotypes CA780308 (Amarelão Ligeiro), CA780329 (Comum Creolo), CA780336 (Pratão Goiano), CA870092 (Branquinho), CA870139 (Noventinha), CA870177 (Arroz Roxo or Caqui), CNA0000937 (Catalão), CNA0001420 (Carreon), and CNA0004623 (Pico Preto) were classified as more productive under water deficit and well-watered conditions.

4. The genotypes CA780044 (Cateto Seda), CA790301 (Ligeiro), and CA980023 (Arroz Canela de Ferro) were classified as productive under well-watered conditions, but they are more sensitive to water deficit.

\section{ACKNOWLEDGEMENTS}

The authors are grateful to Ramatis Justino for assistance in conducting this research and Orygens and Generation Challenge and Drought Phenotyping Networking programs for financial support.

\section{Literature Cited}

Bernier, J.; Atlin, G. N.; Serraj, R.; Kumar, A.; Spaner, D. Breeding upland rice for drought resistance. Journal of the Science of Food and Agriculture, v.88, p.927-939, 2008.

Evenson, R. E.; Gollin, D. Assessing the impact of the Green Revolution, 1960 to 2000. Science, v.300, p.758-762, 2003.

Fukai, S.; Basnayake, J.; Makara, O. Drought resistance characters and variety development for rainfed lowland rice in Southeast Asia. In: Serraj, R.; Bennett, J.; Hardy, B. (ed). Drought frontiers in rice - crop improvement for increased rainfed production. Singapore: World Scientific Publishing, 2008. p.75-89.

Fukai, S.; Cooper, M. Development of drought-resistant cultivars using physio-morphological traits in rice. Field Crops Research, v.40, p.67-86, 1995.

Guimarães, C. M.; Stone. L. F.; Lorieux, M.; Oliveira, J. P. de; Alencar, G. C. de; Dias, R. A. A. Infrared thermometry for drought phenotyping of inter and intra specific upland rice lines. Revista Brasileira de Engenharia Agrícola e Ambiental, v.14, p.148-154, 2010.

Hirayama, M.; Wada, Y.; Nemoto, H. Estimation of drought tolerance based on leaf temperature in upland rice breeding. Breeding Science, v.56, p.47-54, 2006.

Jongdee, B.; Fukai, S.; Cooper, M. Leaf water potential and osmotic adjustment as physiological traits to improve drought tolerance in rice. Field Crops Research, v.76, p.153-163, 2002.
Jongdee, B; Pantuwan, G.; Fukai, S.; Fischer, K. Improving drought tolerance in rainfed lowland rice: an example from Thailand. Agricultural Water Management, v.80, p.225-240, 2006.

Kamoshita, A.; Rodriguez, R.; Yamauchi, A.; Wade, L. J. Genotypic variation in response of rainfed lowland rice to prolonged drought and dewatering. Plant Production Science, v.7, p.406-420, 2004.

Kato, Y.; Kamoshita, A.; Yamagishi, J. Evaluating the resistance of six rice cultivars to drought: root restriction and the use of raised beds. Plant and Soil, v.300, p.149-161, 2007.

Lafitte, H. R.; Courtois, B. Interpreting cultivar x environment interactions for yield in upland rice: assigning value to drought-adaptive traits. Crop Science, v.42, p.1409-1420, 2002.

Lafitte, H. R.; Li, Z. K.; Vijayakumar, C. H. M; Gao, Y. M.; Shi, Y.; Xu, J. L.; Fu, B. Y.; Yu, S. B.; Ali, A. J.; Domingo, J.; Maghirang, R.; Torres, R.; Mackill, D. Improvement of rice drought tolerance through backcross breeding: evaluation of donors and selection in drought nurseries. Field Crops Research, v.97, p.77-86, 2006.

Lafitte, H. R.; Price, A. H.; Courtois, B. Yield response to water deficit in an upland rice mapping population: associations among traits and genetic markers. Theoretical and Applied Genetics, v.109, p.1237-1246, 2004.

Manickavelu, A.; Nadarajan, N.; Ganesh, S. K.; Gnanamalar, R. P; Babu, R. C. Drought tolerance in rice: morphological and molecular genetic consideration. Plant Growth Regulation, v.50, p.121-138, 2006.

Pinheiro, B. da S. Integrating selection for drought tolerance into a breeding program: the Brazilian experience. In: Fisher, K. S.; Lafitte, H. R.; Fukai, S.; Atlin, G.; Hardy, B. (ed). Breeding rice for drought-prone environments. Los Baños: IRRI, 2003. p.75-83.

Pinheiro, B. da S.; Castro, E. da M. de; Guimarães, C. M. Sustainability and profitability of aerobic rice production in Brazil. Field Crops Research, v.97, p.34-42, 2006.

Serraj, R.; Kumar, A.; Mcnally, K. L; Slamet-Loedin, I.; Bruskiewich, R.; Mauleon, R.; Cairns, J.; Hijmans, R. J. Improvement of drought resistance in rice. Advances in Agronomy, v.103, p.41-99, 2009.

Stone, L. F.; Moreira, J. A. A.; Silva, S. C. da. Tensão da água do solo e produtividade do arroz. Goiânia: Embrapa CNPAF, 1986. 6p. Comunicado Técnico, 19

Yue, B.; Xue, W.; Xiong, L.; Yu, X.; Luo, L.; Cui, K.; Jin, D.; Xing, Y.; Zhang, Q. Genetic basis of drought resistance at reproductive stage in rice: separation of drought tolerance from drought avoidance. Genetics, v.172, p.1213-1228, 2006. 